\title{
THE INFLUENCE OF EPHRAIM THE SYRIAN
}

\author{
ANDREW PALMER \\ DEPARTMENT OF THE STUDY OF RELIGIONS \\ SCHOOL OF ORIENTAL AND AFRICAN STUDIES \\ LONDON, UNITED KINGDOM
}

"The intellectual Euphrates of the Church" was augmented by many tributaries. To restrict the study of his influence to that of his undiluted, authentic works would not do justice to the impact of his example. ${ }^{1}$ We need to analyse the vast corpus which goes under

${ }^{1}$ I have used short paragraphs for ease of reference. For more about the speech in praise of Ephraim which was long attributed to Gregory of Nyssa, see the paper by David Taylor in Hugoye 1:2. Sebastian Brock, in the present issue, gives it a seventh-century date. The place where the unidentified author calls Ephraim "the intellectual Euphrates of the Church" is at col. 824A of vol. 46 of J.-P. Migne's Patrologia Graeca. Edmund Beck, "Philoxenos und Ephräm," Oriens Christianus 46 (1962): 61-76, at p. 61, dismisses the possibility that Ephraim the theologian (as opposed to the moralist and the ascetic) had an influence beyond the narrow world of Syriac theology, on the grounds that his theology "must have seemed underdeveloped (rückständig) in comparison with the theology of his great Greek contemporaries" and that the relevant parts of his output, such as the Teaching-Songs (or Hymns) on Faith, "are unlikely ever to have been translated into Greek" (my italics). This ignores the testimony of St Jerome, de viris illustribus 115, who read a volumen by Ephraim on the Holy Spirit in a Greek translation (most of Ephraim's doctrine on the Holy Spirit is in the Teaching-Songs on Faith). The doctrine of the Holy Spirit was elaborated at the Council of Constantinople in 381- after Ephraim's death in 373 and before the date at which Jerome wrote in 392-so it seems likely that this work was 
his name to be able to decide how much of it is indebted to him for at least a part of its content or an aspect of its form. ${ }^{2}$

translated by a theologian who thought that Ephraim's doctrine would be helpful to Greek theologians in performing this task. Beck, for all his familiarity with Ephraim, does not allow for the possibility that the "underdevelopment" of his theology was a matter of conscious choice. Besides, as David Taylor's paper in Hugoye 1:2 shows, the possibility of Ephraim's influence on his "great Greek contemporaries" may have been too rashly discounted; and his indirect influence on Byzantium through the Greek Ephraim and Romanos is not without theological content.

${ }^{2}$ See Beck's article, cited in note 1 and the paper by Sidney Griffith in Hugoye 1:2 (also published in Sobornost, incorporating Eastern Churches Review, 20:2 [1998]: 21-40). Any study of Ephraim himself should be based on his authentic works only, and even there only with caution. Francis Crawford Burkitt's study of S. Ephraim's Quotations from the Gospel = Texts and Studies 7:2 (Cambridge, 1901) starts by listing the manuscript sources of the Roman edition (which it criticizes very severely) and the other manuscripts in which the works edited there have been transmitted; then adds the works edited by J.J. Overbeck (S. Ephraemi Syri ... aliorumque opera selecta, Oxford, 1865) and T.J. Lamy (S. Ephraem Syri bymni et sermones, 4 vols., Louvain, 1882-1901 — the last volume had not yet been published) with their manuscript sources; and lists as genuine (on p. 24f.) all those attested by at least one manuscript dating from before the Arab Conquest of the early seventh century. On p. 23 he writes: "A mechanical rule such as this no doubt excludes some genuine writings, but the list at least escapes the charge of having been constructed to suit a pre-determined critical theory." This list, therefore, should not be represented as an attempt to tackle the problem exhaustively and systematically. Moreover, Burkitt's method is flawed: it cannot account for interpolations, supposititious works of early date, or authentic works attested only by later MSS. His list is certainly incomplete, in that it does not include the Diatessaron Commentary, which was discovered more than half a century afterwards, in 1957; but it may be incomplete-or too inclusive-in other respects as well. Other lists have been drawn up by Louis Leloir, Évangile d'Ephrem d'après les oeuvres éditées: receuil des textes (CSCO 180, Subsidia 12; Louvain, 1958), ivf.; Arthur Vööbus, Critical and historical studies in Ephrem the Syrian (Stockholm, 1958); Edmund Beck, "Éphrem le syrien (saint)," Dictionnaire de Spiritualité, 26/27 (Paris, 1959) 788-800, at 790f.; Ignatius Ortiz de Urbina, Patrologia Syriaca (Rome, 1965), chapter 3; and Sebastian Brock, St. Ephrem the Syrian: Hymns on Paradise (New York, 1990) 230-33 (Brock, presumably following Urbina and Baumstark, does not even mention the attribution to Ephraim of a long work on Joseph, on which see the following note). 
What became attached to Ephraim's name was decided by more than one factor. If something was written in "Ephraim's metre," a series of couplets of heptasyllables, or seven-syllable lines, it might be attributed to him, especially if the true author was not known. This happened in Syriac; ${ }^{3}$ but it happened even more

${ }^{3}$ The ballad on the mission of St Andrew to the Cannibals (on which see the paper by Michel van Esbroeck in this issue) is implausibly attributed to Ephraim. The twelve-ballad epic on Handsome Joseph (edited by P. Bedjan in 1887 [corrected and augmented edition: 1891] and by T.J. Lamy, with a Latin translation, in his vol. III (1889)—in Aleppo in 1997 I saw, in a photocopy without the date of publication, a Lebanese Maronite edition with an Arabic translation by a twentieth-century Assemani and an introduction by Cardinal Eugène Tisserant, which praises the dramatic sense of Ephraim as the author) is attributed to Ephraim by all the MSS which have the complete epic; but they are all late. Anton Baumstark, Geschichte der syrischen Literatur (Berlin, 1922) 62f. argues that this epic belongs to Balai, and his argument appears to have been accepted by other scholars. The question has never been treated at length. Two books (originally three: fol. 154b) of the heptasyllabic epic are attributed to Balai in Br. Lib. Add. 12,166, foll. 1-154, a MS of the sixth century ( = no. 742 in W. Wright, Catalogue of the Syriac MSS in the British Museum, 3 vols. [London, 1872], vol. 2, 674-6). The pentasyllabic metre is Balai's trademark, but he may have imitated Ephraim's metre. There may be some mistake in this attribution; for example, Balai's name may have appeared at the end of the exemplar from which the scribe copied, but it may have applied to a supplement on the translation of the bones of Joseph to Constantinople in the late fourth century (Br. Lib. Add. 7190, foll. 329a-32b) and been mistakenly applied to the Books extracted from the epic by the scribe of Add. 12,166. The early mediaeval Add. 14,590 includes Book Two, without any attribution, in a volume of compositions by Ephraim and Jacob of Serugh. Baumstark admits that it is one of the best poems in Syriac; if Balai was such a good poet, it is surprising that so little of his work is known. A comparison of style and content shows a great affinity with Ephraim, which seems even greater in view of the gulf between the authentic Ephraim and the ballad on Andrew. The epic on Handsome Joseph is, at the least, a very good imitation of Ephraim. I would add another argument. In the preface to his Commentary on Genesis, Ephraim says he has commented at greater length on this book of the Bible in his "ballads (mimre) and teaching-songs (madroshe)." The Teaching-Songs on Paradise answer to one part of the book; and here and there throughout his teaching-songs he returns to the subjects of the Creation and of Abraham; but if he did not write at length in the balladform on Joseph, it is difficult to see why Ephraim's preface mentions 
in Greek, from which "Ephraim" was translated into many other languages. ${ }^{4}$

Another factor was Ephraim's supposed character. If something seemed "Ephraimic" by its content, regardless of the form, it might be attributed to him. ${ }^{5}$ What is the character of Ephraim is a question which has many answers: one for each "picture' of Ephraim which has been constructed. ${ }^{6}$ Ephraim has

ballads, or where else he might have treated of the last part of Genesis " $a t$ greater lengtb" than in his prose commentary. Yet, on balance, perhaps, the attribution to Balai is the more credible, because it seems unlikely that such a poem would be attributed to anybody other than Ephraim, unless it was really written by Balai; whereas, if the later MS tradition depends on an exemplar or exemplars which lacked any attribution, the poem would naturally be attributed to Ephraim.

${ }^{4}$ See Alain Desreumaux's paper on Ephraim in Christian Palestinian Aramaic in Huggye 1:2. Samir Khalil Samir spoke at the conference on the Arabic Ephraim; I was not able to discover if anyone is working on the Slavonic Ephraim; Bernard Outtier's paper on Ephraim in Armenia and Georgia is published in this issue. Please note that Ephraim used a large number of different metres in his stanzaic poetry; the heptasyllablecouplet was used in his balladic mimre, such as those on Nicomedia, translated into Armenian heptasyllabic couplets.

${ }^{5}$ Ephraim was reputed to have written commentaries on all the books of the Bible (see [Ps.-]Gregory of Nyssa, Migne, PG 46, col. 829B) and many commentaries have been attributed to him - and printed as authentic in the Roman edition-which scholars now consider to be falsely attributed (see Ignatius Ortiz de Urbina, Patrologia Syriaca [Rome, 1965], chapter 3). He wrote a great deal on the subject of repentance, so any anonymous homily on repentance might be attributed to him (Arthur Vööbus, Critical and historical studies in Ephrem the Syrian [Stockholm, 1958] made a concentrated, though little appreciated, effort to distinguish authentic from inauthentic ascetical and paraenetical texts attributed to Ephraim). He wrote eloquently on the symbols to be found in a pearl (e.g. Teaching-Songs on Faith 81-5), so it was easy for a tract (Roman edition, Greek vol. 2 [Rome 1743] 259-79) which annexed the symbolism of the pearl to the Chalcedonian formula to be attributed to him. (See p. 263F: "The pearl of great price partakes of the two natures so as to show that Christ, being the Word of God, was born as a human being from Mary.")

${ }^{6}$ For Ps.-Gregory and others Ephraim was very effective in the war of words against the heretics. For Sozomen (Ecclesiastical History 3:16) he was a solitary monk, who "refrained from the very sight of women." For the later Greek monastic tradition he was the opponent of laughter, which, when mixed with seriousness, "easily destroys souls." On these 
been a model for many; but we have to ask which version of Ephraim each admired.

There was also the process known as "interpolation." Ephraim wrote a poem and left, we may assume, a certain amount of space on the page, which seemed to some readers an invitation to compose extra verses "in the style" of Ephraim. When the manuscript was copied at the request of someone living at a distance, these verses were inserted in the text and transmitted as Ephraim's. ${ }^{7}$

Besides these three factors which account for the swelling of the mainstream, there is another which means that the portion of the original river in that stream has been reduced from time to time. This is the decision of medieval copyists not to pass on works by Ephraim to future generations. In some cases this has led to the permanent loss of those works; in others, they have been recovered. ${ }^{8}$

changing images, some of which seem designed to protect Ephraim from an anticipated imputation of too much fondness for women, or too much humour in his presentation, see the paper by Sebastian Brock in this issue and that by Sidney Griffith in Hugoye 1:2 and Sobornost 20:2 (1998): 21-40.

7 See Louis Leloir, Doctrines et méthodes de S. Éphrem d'après son Commentaire de l'Évangile Concordant (Louvain, 1961) 53; Kathleen McVey, Ephrem the Syrian: Hymns, The Classics of Western Spirituality (New York, Mahwah, 1989) 298f., n. 124; and my article in Parole de l'Orient 20 (1995): 129-200: "Words, Silences, and the Silent Word: Acrostics and Empty Columns in Saint Ephraem's Hymns on Faith." If I am right and the acrostics in the Hymns (or Teaching-Songs) on Faith ought to be sequences of single letters, unless a meaningful pattern is created by reduplication and triplication (as in no. 49), then a number of stanzas need to be removed to restore the original text of e.g. nos. 26 and 32, including those which contain, uniquely in this book, the plural of kyono used interchangeably with the singular and that other key-word, qnumo, used adverbially (qnumoith) to mean "essentially"- two usages which figure prominently in Beck's treatment of these terms (Die Theologie des heiligen Ephraem in seinen Hymnen über den Glauben = Studia Anselmiana 21 [Rome, 1949] 16f. and 18f.). In general, the presence in Ephraim's genuine works of spurious interpolations means that, like Ephraim himself in 53:4, 8 and 13f., we cannot accept one witness to his genuine usage (such as the single place where Ephraim speaks of two natures in Christ: Homily on Our Lord XXXIV, a passage regarded by the editor, for other reasons, as an interpolation), but must have three at least.

${ }^{8}$ Almost all the works edited by Beck would have been lost, had it not been for the survival of a handful of manuscripts in the Syrian 
The time in which we live is the best time there has been, so far, for assessing the influence of Ephraim. If we mean by that the influence of the medieval Ephraim corpus, whether in Greek and Latin, or in the languages of Oriental Christians, some progress has been made in our century with the study of the transmission of knowledge in the Middle Ages, though much remains to be done. ${ }^{?}$

If, on the other hand, we mean the reconstruction of the authentic Ephraim and the assessment of his own original contribution and the extent to which that has lasted or been revived, our century has seen the first critical editions of his surviving Syriac works and the first unbiased attempts to decide which of the works attributed to him is authentic. Here, too, though, much remains to be done. ${ }^{10}$

Monastery in Egypt. What is extant is evidently only a small percentage of his output, even if Sozomen (Church History III 14) exaggerates in saying that he wrote three million lines of poetry. For one thing, his commentary on the Psalms, to which his poetry refers in very many places, has not even survived in Armenian, which preserved several of his commentaries; as a liturgical poet Ephraim must have felt a special attachment to the Psalms.

9 See, for example, Ephrem Lash's website on "Ephrem:"

http://www.orthodox.org.uk/ephrem.htm

${ }_{10}$ Petrus Benedictus on the first page of his preface to the reader in Sancti patris nostri Ephraem Syri opera omnia, Syriac vol. 1 (Rome, 1737) made the ridiculous claim that the stamp of Ephraim's style was so clearly on all the (Syriac?) works attributed to him that "we are forced to say" they are either all by him, or none of them are by him (dicere cogamur, aut opera omnia, quae hactenus Ephraemi praetulere nomen, Ephraemi calamo fuisse exarata, aut nulla.). Burkitt thought the criterion of manuscript tradition more objective than that of style, which is to go from one extreme to another. For Beck, who only used the more ancient MS witnesses in his editions, it was enough for a work to have a late mediaeval MS tradition to render its authenticity suspect. (The only extant MS of the probably second-century Syriac Odes of Solomon is of about the fifteenth century, which shows that this assumption is wrong.) With such flawed criteria, Burkitt's and Beck's selection of authentic works can hardly be accepted without further examination. Ortiz de Urbina adds the criterion of quotations from Scripture, meaning, presumably, the judgment whether the author quotes from Ephraim's text of the Bible. No scholar, to my knowledge, has given thought to the likelihood that Ephraim's teaching developed over time, so that he may, in two works separated by an interval, contradict himself. 
The lesson from the past is that each culture constructs a picture of Ephraim according to its own lights. ${ }^{11}$ Whatever picture we ourselves can reconstruct, it is likely to bear the stamp of our own concerns, even if we make an effort to be objective. For example, a young, secular Englishman is likely to give a greater emphasis to sexual language than a monk of Mount Athos would do. ${ }^{12}$

${ }^{11}$ In addition to the humourless Ephraim, the misogynistic Ephraim, the Chalcedonian Ephraim, and the Lutheran Ephraim, our century has constructed the feminist Ephraim (Farida Boulos represented Ephraim at the conference as an emancipator of women and contrasted the repressive attitude of the Syrian Orthodox Church today), the ecological Ephraim (compare the paper by Robert Murray in this issue) and the Ephraim of thinly veiled sexual references and even of teasing innuendoes (see the following note). He seems to be so ambiguous that he can be moulded to the mind of his reader. This is perhaps part of the secret of his perennial appeal: Benedictus, Sancti patris nostri Ephraem Syri opera omnia, Syriac vol. 2 (Rome, 1740), preface to Cardinal Quirinus: Marmora, ac metalla tempus tandem consumsit [sic], S. Ephraemi lucubrationes nulla obliterabit dies ("Over the centuries, time has consumed monuments made of marble and of bronze, but the day will never dawn when the writings of Saint Ephraim are so worn away that they cannot be read").

12 In a number of conference papers given in Cambridge, in Kottayam, in Uppsala, in London and elsewhere in recent years, I have argued that human sexual biology, male and female, provides Ephraim (whose mature commitment to chastity I do not question, though he saw no reason why this should entail the separation of the sexes: see the empathetic treatment by the Benedictine monk, Louis Leloir, "Le Témoignage monastique de S. Éphrem," in his Doctrines et méthodes de S. Éphrem d'après son commentaire de l'Évangile Concordant [Louvain, 1961]) with a pervasive frame of reference, which he transfers in all its detail onto the spiritual plane. He is readier to name the female sexual organs explicitly than the male, to which however he alludes, indirectly, but quite unmistakably, e.g. in Teaching-Songs on Faith 25 and 75, which should be read in the original by any reader who is willing to try to see what I mean. If I have not published these papers, it is, at least in part, because I am aware that more work needs to be done on the Syriac sexual vocabulary before my argument can be made sufficiently objective. Unfortunately, the Syriac Book of Medicines published in two volumes by Ernest Alfred Wallis Budge (London, 1913), which is, in the main, the translation of some Greek lectures given by an Alexandrian disciple of Hippocrates, hardly contains any sexual vocabulary at all (perhaps it was censored by monastic scribes!). Section 12 of Ephraim's advice to a young virgin, published in 
What makes the subject so worthwhile is that Ephraim can appeal both to the monk of Mount Athos and to the young secular Englishman. Ephraim, or Pseudo-Ephraim, seemed to John Wesley "the most awakening of the ancients;" 13 to Edward Pusey, whose churchmanship was so different from that of the Wesleys, the genuine Ephraim seemed the great exponent of mystical typology. ${ }^{14}$

Some problems can be weighed, but with an uncertain result. Did Ephraim influence the Cappadocian Fathers or they him (or was there, as Beck would have it, no sharing across that particular barrier of languages and mountains)? ${ }^{15}$ Did Ephraim give a decisive impetus to the Christian practice of singing hymns in church? ${ }^{16}$ Did Byzantium adopt his melodies? ${ }^{\text {17 }}$

C.W. Mitchell, Prose Refutations, vol. 2 (1921) lxxxii and 174, confirms that shawpo and nqopo both have sexual connotations for Ephraim, as they do in certain other places cited in the lexica: "Let fire be an example to you, which is buried and dead in a hidden place, but which the friction (shampo) of one piece of wood with another brings to life, leading to the destruction of both. For once she ('fire' is feminine in Syriac) has come to life, she turns on the individual (or substance: Syriac qnumo) which has brought her to life by his intercourse (nqopo) with her and burns him up ('wood' is masculine in Syriac)." This language, combined with the second person feminine singular, suggests that Ephraim was not immune to the pleasure of speaking, delicately, to a single woman about sex, or of imagining that he was doing so. In a passage of the Commentary on the Gospel preserved only in the Armenian translation (12:6) he underlines the fact that Jesus was found speaking alone and without a witness to a disreputable Samaritan woman. (When I made a similar remark to a monk on Mount Athos who thought it impossible to be saved "in the world" because of the presence there of women, he protested that Christ was God and therefore different, presumably meaning that, while He was human in every other way, He did not know desire [and therefore was not completely human?]; compare Hannah Hunt's paper in Hugoye 1:2, n. 52.) See also the anthology attached to this article, especially the Teaching-Song on the Nativity.

${ }^{13}$ See the paper by Gordon Wakefield in Hugoye 1:2.

${ }^{14}$ See the paper by Geoffrey Rowell in this issue.

${ }^{15}$ See the paper by David Taylor in Hugoye 1:2.

${ }^{16}$ F. L. Cross, Oxford Dictionary of the Christian Church, 3rd ed. by E.A. Livingstone (Oxford, 1997) 551 claims: "His [Ephraim's] liturgical poetry had a great influence on the development of both Syriac and Greek hymnography." E. Beck, "Ephraem Syrus," in Reallexikon für Antike und 
For our purposes it is not vital to assess the debt of Ephraim to Bardesanes (Bar Dayson) and his son, Harmonios, or that of these earlier Syriac poets to the Greeks. ${ }^{18}$ Ephraim describes the poetry of Bardesanes in terms reminiscent of his own art of balancing phrases of equal length ${ }^{19}$ and a fragment shows that

Christentum V, 521-31, discusses on pp. 529-31 the influence of Ephraim on the Greek and the Latin poetry of early mediaeval Christianity: "In the field of metre Ephraim became a pathbreaker also for Greek and Latin literature [...] His contribution to this development appears to have been the stanzaic composition of responsorial songs and the isosyllabic principle. The transference of the latter into Greek poetry reveals itself in the isosyllabic works of the 'Greek Ephraim.' [...] A general consideration favours the Syrian as the leader here: the principle of parallelism often leads almost automatically - given the uniformity of Semitic nominal and verbal linkage-to an equal syllable-count."

${ }^{17}$ The fact that, e.g. Ephraim's Syriac Ballads on the Repentance of the Ninevites were translated into identical Greek couplets of sevensyllable lines (well edited by Mercati) suggests that the Greek-speaking recipients adopted the Syriac melody, even if musicological research to date has not discovered a method by which to reconstruct, from the divergent oral traditions, the early forms of Syriac melodies and to relate these to early Byzantine melodies. William Dalrymple, From the Holy Mountain: A journey in the shadow of Byzantium (London, 1997) 177 credits to Gianmaria Malacrida the assertion that "the chants of ancient Edessa should be the oldest original chants in the Christian tradition. What we heard tonight [9 September, 1994, in the Church of St George, in the Old Syrian quarter of Aleppo] shows every sign of being the unadulterated music of late antique Edessa." However, this book, while appearing scholarly by its bibliography, does have a tendency to sensationalise and, like Thucydides, Dalrymple writes, not what his acquaintances actually said (as I know from speaking to some of them about it), but what the author finds it appropriate that they should say in his book.

${ }^{18}$ Sebastian Brock has studied Sozomen's version of events critically and come to the conclusion (agreeing with Rubens Duval in his Litterature syriaque [Paris, 1899]), that he very much exaggerates the Greek influence on Syriac poetry; see his "Syriac and Greek hymnography, problems of origins," Studia Patristica 16 (= Texte und Untersuchungen 129; 1985) $77-$ 81, reprinted in his Studies in Syriac Cbristianity (Aldershot, 1992), ch. VI.

${ }^{19}$ Teaching-Songs against Heresies, 53:5; the word gbal, "moulded" (as the Creator "moulded Adam" out of clay) in line 1, suggests that Ephraim may have attributed a certain originality to Bardesanes in the matter of form. 
Harmonios used heptasyllables, which came to be Ephraim's mark. ${ }^{20}$

But it was through Ephraim that the forms of Syriac poetry came to influence those of Greek poetry, not through Bardesanes and Harmonios. Whatever these may have learned from the Greeks, it was not isosyllabic metres, which were probably first used in Greek in the late fourth century. Bardesanes may have invented stanzaic poetry, but Romanos derived his models from Ephraim. ${ }^{21}$

Translations of Ephraim into Armenian were made at the beginning of the fifth century, just after the Armenian alphabet was invented. Ephraim's art is akin to that of the bard in an oral culture and so was well designed as a literary model for new compositions by the Armenians, who knew only an oral culture. He was indeed imitated in Armenia, as happened later in Egypt and in Ethiopia, too. 22

Ephraim was aware that literature lacks the spontaneity of word-of-mouth communication; ${ }^{23}$ yet even when he was writing to

20 Burkitt, "Introduction," in C.W. Mitchell, S. Ephraim's Prose Refutations, vol. II (Cambridge, 1921).

21 There are references in David Taylor's article in Hugoye 1:2 to the work of Petersen, Brock and others on Ephraim's influence on Romanos the Melode. More needs to be done on this, in particular where both poets have treated the same biblical theme, such as Noah's Flood; here (as an exercise carried out in 1990 by students of Byzantine history in Groningen showed) a detailed comparison is instructive. There is a clear account of Romanos's likely formal debt to Ephraim in Archimandrite Ephrem Lash's introduction to his translation of On the Life of Christ: Kontakia in the Sacred Literature Series (San Francisco etc., s.d. [1995?]) $\mathrm{xxx}$.

22 The Copts greatly revere Ephraim and so do the Ethiopians, who are constantly singing from a book of the praises of Mary (waddase Maryam), which they believe to be by him. He is represented, often with Mary, in the paintings on the walls of several Ethiopian monasteries and churches, as I have seen from photographs taken by Joachim Gregor Persoon, a PhD research student at the School of Oriental and African Studies in London.

${ }^{23}$ Ephraim, Against the false teachers, tract 1 of 5, in J.J. Overbeck (ed.), S. Ephraemi Syri ... aliorumque opera selecta (Oxford, 1865) 21; translated by C.W. Mitchell, S. Ephraim's Prose Refutations, vol. I (1912) i: "Behold, I am writing willingly something that I did not wish to write. For I did not wish 
be read, he maintained a lively interaction with his reader. This is the secret of his "awakening" quality. He surprises and puzzles, poses questions and riddles, gives room for more than one answer, and even appears to go too far, then to check himself. ${ }^{24}$

This rhetorical style was more difficult to imitate than his metrical technique; but some succeeded, and Wesley found this "awakening" quality in the Greek Ephraim, as edited in Oxford, at the Sheldonian Press in 1709 , by Edward Thwaites. ${ }^{25}$ Both the metres and the lively style are transferable skills, which may be detached and used to convey ideas not entertained by Ephraim.

At the time of the Italian Renaissance, Ambrose of Camaldoli had already been impressed by the Greek "Ephraim," although the writers who go under that name are often far inferior to Ephraim himself. ${ }^{26}$ Something of his genius still shines through the Greek corpus, so that Cosimo de' Medici, for all his refinement, could confidently be expected to overlook the occasional barbarism. ${ }^{27}$

that a letter should pass between us, since it cannot ask or be asked questions; but I had wished that there might pass between us a discourse from mouth to ear, asking and being asked questions. The written document is the image of the composite body, just as the free tongue is the likeness of the free mind. For the body cannot add or subtract anything from the measure of its stature, nor can a document add to or subtract from the measure of its writing, But a word-of-mouth discourse can be within the measure or without the measure."

24 Compare Ephraim's portrayal of God's teaching-methods in Teaching-Songs on Faith 38:1: "The love of You makes me keen, / eager not to displease you, Lord. / It lulls, rouses, curbs and restrains; / trains, gives rein; uses all means to bring me to Life. / [Response:] Glory to Him who teaches all!"

${ }^{25}$ It is unlikely (as emerged from a discussion at the conference) that Wesley knew any of the volumes of the Roman edition of Ephraim's Syriac works, which began to be published in 1737 . Wesley had done the greater part of his patristic reading while at Oxford before this date. See the paper by Gordon Wakefield in Hugoye 1:2.

${ }^{26}$ See the paper by Ephrem Lash in this issue; he distinguishes three distinct "voices" from the chaotic din of the collection.

27 Ambrose of Camaldoli, edition of the Greek Ephraim (Florence 1481), prefatory letter, as edited in the Latin edition of the complete works of Ephraim, printed in two volumes at Venice in 1755 and 1756 by [Gianbattista Albrizio and] Gasparo Gerardi, Prolegomena, section 13, extracts, with the conclusion, translated from the Latin: "Lately I came upon a traveller who had come to us (they said) from Syria, an old man, 
Seven Latin texts attributed to Ephraim had long been in circulation in the monasteries of Europe; but although Theodore of Tarsus brought the Greek (and, conceivably, some of the Syriac) Ephraim to Canterbury in the seventh century, ${ }^{28}$ few European scholars had been able to read him in anything but Latin. He was widely read in that language, however, as recent research shows. ${ }^{29}$

The Latin Ephraim had a certain influence on German literature in the eighth and ninth centuries; and later, it seems, on Hildegard of Bingen. ${ }^{30}$ And something of the original Ephraim was

tall of stature, though now bent with age, calm and dignified of countenance, whose own person, as well as his dress, bore the evident marks of sanctity. His eyes welled with tears, but in such a way that nothing of his dignity was removed from that face, but rather much was added to it in the way of authority and grace. In this way his face was not made dirty or squalid by that almost perpetual profusion of tears, but became thereby altogether more serene, more luminous, more composed; and elicited the affection of all those who looked upon him. [...] But why do I say so much about this guest of ours? You will take the risk of judging him most definitively for yourself and you will decide what opinion should be held about him. If he seems sometimes to adopt a rough and ready style and to omit almost entirely the cultivation of rhetoric, that is in part to be allowed him as an old man and an imitator of the simple speech of our ancestors, in part to be attributed to the matter, which is altogether not of a kind to be suited to rhetorical decoration, and in part to be laid at my own door, because I have acted with immoderate haste. For in my anxiety to send him to you as soon as possible, and so to comply with your wishes, I have let him go in a less polished state than he might perhaps have acquired, had he stayed with me for a slightly longer period of time. [...] Here he is, then; take him in your arms, apply your ear and your mind by preference to him. Now I'll leave the two of you together. Goodbye!"

28 See the paper by Jane Stevenson in Hugoye 1:2; the earliest manuscripts of works belonging to the Latin Ephraim corpus, which is translated from the Greek, are apparently of the seventh century.

${ }^{29}$ See the paper by David Ganz in this issue, with his tribute to Tom Pattie.

30 Nabil el-Khoury, Die Interpretation der Welt bei Ephraem dem Syrer = (Tübinger theologische Studien 6; Mainz, 1976) 23: "[the influence of Ephraim is attested] even for Old High German poetry (Muspilli, 8th/9th cent.; Otfrid, 9th cent.).” Margot Schmidt, of the University of Eichstätt in Germany, is preparing a paper on "Some Parallels Between Ephraim and Hildegard of Bingen," which (her health allowing-it most 
preserved in the Latin. For example, Ephraim's predilection for the name of "Physician" in referring to Christ. This apparently entered Anglo-Saxon usage through Latin Ephraim-texts. ${ }^{31}$

Ephraim is widely read in Orthodox monasteries, whether in Greek, or another language. 32 What is more, his fame was proclaimed by many wall-paintings in Eastern Orthodox churches. ${ }^{33}$ Plethon, the Edward Gibbon of Byzantium, would have had nothing to do with the Greek Ephraim; but Ambrose of Camaldoli shows that he was not the only arbiter of taste in Renaissance Florence.

Gerhard Voskens was the first of the humanists of Northern Europe to attempt an edition of Ephraim, one which was almost entirely limited to the corpus in Latin and in Greek. ${ }^{34}$ Reading the

unfortunately prevented her from attending the conference) will be published in another issue of Hugoye.

31 Patrick Sims-Williams, "Thoughts on Ephraim the Syrian in AngloSaxon England," in Learning and Literature in Anglo-Saxon England, edited by M. Lapidge and H. Gneuss (Cambridge, 1985) 205-26.

32 When I visited Mount Athos in 1977, I heard (Pseudo-)Ephraim read aloud in the refectory to the monks at the monastery of Agiou Pavlou. Dorin Oancea gave a paper at the conference about Ephraim's influence on Eastern Orthodox theology, an influence sweepingly denied by Edmund Beck.

33 See the beautifully illustrated paper by Zaga Gavrilovic in Hugoye $1: 2$.

34 The two-volume Venetian edition of Ephraim (1755/6), which reprints the Latin works attributed to Ephraim together with the Latin translations of the Greek and Syriac works, calls the roll of those who have edited Ephraimic texts as follows: Ambrose of Camaldoli, Zino of Verona, Julius Clemens, Aloysius Lipomanus, Laurentius Surius, Claude Chantelou, Franciscus Combefisius and Balthasar Corderius, Guido Fabricius Boderianus (Antwerp, 1572: two sermons from the Syriac), Gerardius Vossius [Voskens] (Rome, 1589, 1592, 1593, 1598; including, it would appear, a translation of the well-loved Syriac alobo bab yulpono l-ayno d-robem yulpono, which is still sung by students at the Seminary in the Monastery of Mor Gabriel in Tur 'Abdin), John, Cardinal Bona and Abraham Echellensis (Rome, 1645; including two canticles on Mary and the Magi from the Syriac), Jacobus Gretserius, Jean-Baptiste Cotelerius, Patricius Junius, Edward Thwaites. All this scholarship is both inaccessible and of little use today; but even this empty roll-call attests to the interest of succeeding generations, which added to "the influence of Saint Ephraim.” 
result of his work, a Protestant scholar, Johannes Kohl, claimed that Ephraim understood the Lord's Supper much as Martin Luther did. Catholic scholars were not slow to vindicate his catholicity. ${ }^{35}$

The first (French) Catholic project to edit Ephraim came to nothing. The second succeeded in editing not only the Latin and Greek works, but also a vast number of Syriac works attributed to Ephraim, many of them genuine. ${ }^{36}$ These had been recovered from oblivion when manuscripts were sold to representatives of Pope Clement XI. by a Coptic monastery in Egypt c. 1701.37

Ephraim's entire output was probably still being copied out anew up to two hundred years after his death. Fifth and sixthcentury manuscripts must have come into the possession of

${ }^{35}$ Roman edition (see next note), vol. I (1737), Editor's Preface, p. 3: When the Syrians read E. in this edition, they will see that "the Romans have not abandoned the Syrian Fathers, but the Syrians themselves have abandoned their own tradition." This will lead them to submit to the See of Peter, "without which the unity of the Catholic Church cannot be held together" (siné qua Catholicae Ecclesiae unitas constare non potest). The book will be read-and the wealthy patron, the cardinal bishop of Brescia, thanked- " "by the Indians of the Coast of Malabar and the Aramaeans of the Mountains of Kurdistan." More than one of the volumes of the Roman edition contain long refutations of "Kohlius." On the Vatican's surprisingly recent declaration, in 1920, that Ephraim is to be regarded as a "doctor ecclesiae," see the paper of Sidney Griffith in Hugoye 1:2 and Sobornost 20:2 (1998): 31-40.

36 Sancti patris nostri Ephraem Syri opera omnia quae exstant graece, syriace, latine, in sex tomos distributa ad MSS. Codices V aticanos, aliosque castigata, multis aucta, interpretatione, praefationibus, notis, variantibus lectionibus illustrata nunc primum sub auspiciis Clementis XII. Pontificis Maximi e Bibliotheca Vaticana prodeunt: Syriacum textum recensuit Petrus Benedictus Societatis Jesu, notis vocalibus animavit, latine vertit, \& variorum scholiis locupletavit, Syriac/Latin vols. I-III (Rome, 1737, 1740, 1743); Greek/Latin vols. I-III (Rome, 1732, 1743, 1746).

${ }^{37}$ Roman edition (see previous note), Syriac vol. I (1737), Editor's Preface, p. 2 (translated from the Latin): "[Those who judge the Ephraim of Voskens or of the Oxford edition,] who stammers in Greek through no fault of his own and addresses his fellow-monks, for the most part, in an undistinguished style, to be some desert-loving Greek or other from the crossroads, [are going to recognise, when they read this] most eloquent teacher putting forward his arguments in his own words and with his own inimitable voice, that the simplicity is their own." 
various Mesopotamian monasteries. In the following centuries they were excerpted for use in the Liturgy and from then on only these excerpts were transmitted by the Syriac scribes of East and West. ${ }^{38}$

The reputation of Ephraim did not decline, although knowledge of his work declined sharply. What knowledge there was now existed only among the monks who learned the ancient language. They were not much interested in speculation. The monk Aaron washed out most of the only extant copy of the refutations of Marcion, Bardesanes and Mani and wrote out other texts on the leaves. ${ }^{39}$

Before washing the leaves, Aaron copied out the only text which did interest him: a short series of words of advice to a female virgin in poetic prose. ${ }^{40}$ This single action sums up the whole process by which the sensitive, fanciful and ingenious wordpainter and speculative philosopher was reduced to a fanatical and humourless moralist and an ungentlemanly opponent of the heretics and the Jews.

This might be seen as poetic justice. Ephraim owed his genius not to his devotion or his memory of the Bible, impressive as they undoubtedly were, but to his education in a wide-ranging speculative school and his exposure to laymen as well as clergy, women and children as well as men, the married (like his own sister, whose son 'Absamya became a poet) as well as the celibate. ${ }^{41}$

38 Sebastian Brock, "The Transmission of Ephrem's madräshe in the Syriac liturgical tradition," in E. A. Livingstone (ed.), Studia Patristica 33 (1997): 490-505. Individual stanzas, however, have a textual integrity of their own; in the light of the common experience of textual editors, that the most recent MSS are not necessarily the worst ones, the entire history of the transmission of each stanza of Ephraim's work should ideally be evaluated. There are corrupt passages and small lacunae in the ancient MSS collated by Beck where the breviaries might give MS authority to otherwise purely editorial conjectures and supplements.

${ }^{39}$ C.W. Mitchell, S. Ephraim's Prose Refutations, vols. I and II (1912 and 1921), in the Prefaces and the Introduction by F.C. Burkitt.

40 Mitchell, S. Ephraim's Prose Refutations, vol. II (1921) lxxxii ff. and (Syriac) $174 \mathrm{ff}$.

41 See my paper in Hugoye 1:2; 'Absamya, Ephraim's sister's son, wrote a poem on the invasion of the Huns, as we read in the sixth-century Chronicle of Edessa, which makes use of the official archives of the diocese and the former kingdom. 
But Ephraim was insufficiently aware of how much he owed to city-life. He argued that, since it was impossible to know everything about the world, it was not worth bothering about the things one doesn't know. ${ }^{42} \mathrm{He}$ praised the knowledge that one is ignorant as the greatest wisdom. Socrates, for this reason, was a radical rethinker; but for Ephraim, thinking taught only the limits of thought.

[27] Ephraim was clear on the subject of marriage, that it was one of the three ways blessed by God, and he balanced Paul's doctrine that the most perfect way is singleness with a warning to the single not to get above themselves. ${ }^{43}$ However, his own enthusiasm for virginity, coupled with the fact that monks transmitted his works selectively, makes him seem less even-handed than this theory.

By giving his support to self-sufficiency and to uncritical belief, by branding dialectic as the devil's work and opposing Greek philosophy to the pure simplicity of the Gospel, Ephraim undermined civic values and contributed to the dearth of scientific thought which marks the Middle Ages. He helped to form the mind of those who washed out his own most interesting work.

Ephraim, "God's lyre," saw his name as a combination of the words "fecundate' and "sea." "The prophet of the Syrians"- their "greatest teacher"- did inspire lesser poets, one of whom called him "the ocean on which all the ships of poets sail" (Jacob). But Ephraim, like an encratite attacking sex, campaigned for the abolition of the very union of cultures which gave birth to his unique genius.

42 Mitchell, S. Ephraim's Prose Refutations, vol. I (1912) xvi (Syriac, ed. J.J. Overbeck, p. 41): "when we know that we cannot know, we cease to investigate." The whole of the preceding passage is Ephraim's answer to the accusation of anti-intellectualism evidently levelled against him.

${ }^{43}$ See Burkitt's Introduction to Mitchell, S. Ephraim's Prose Refutations; L. Leloir, Doctrines et méthodes de S. Éphrem (Louvain, 1961) 58; and the Armenian version of the Commentary on the Diatessaron, edited by Leloir, 15:5. For Ephraim, Christ was "everything to Himself" and this was the model which the virgin sought to imitate (see the end of the text referred to in note 40). Compare the paper by Thomas Kunammakkal in this issue. 
Lip-service was paid (as it is by many Syrians today ${ }^{44}$ ) to books which were not often read and which therefore ceased to be copied. Mesopotamian monasteries in the ninth century were not reluctant to sell for cash their best manuscripts of Ephraim's works to Moses, the abbot of the Syrian Orthodox Monastery of the Godbearer in the Nitrian Desert, a dedicated collector of books. ${ }^{45}$

Virtually all the manuscripts in which Ephraim's authentic works have been preserved come from the collection started by Moses. Some were sold to the Vatican, as I have mentioned. One boatload of these foundered in a sudden storm and sank in the Nile. Amongst the books which went down was a codex of Ephraim (no. 111). This "pearl," partly obliterated, was fished up. ${ }^{46}$

Other Nitrian codices found their way, in the early nineteenth century, to the British Museum. Overbeck, Lamy, Bickell and

44 Kottayam (State of Kerala, India), Ma'arat Sayyidnaya (near Damascus), Aleppo, Glane/Losser (Holland) and other places boast Syrian Christian centres named after Saint Ephraim; Thomas Kunammakkal, one of whose papers appears in this issue, and Aho Shemunkasho, who is doing a doctorate at Oxford, are only two of a number of Syrian Christian scholars who are now studying Ephraim. Yet it remains true of the majority of Syrian Christians that lip-service is paid to the genius of one whose genuine works are little known.

45 J. Leroy, "Moïse de Nisibe," Orientalia Christiana Analecta 197 (1974): 457-70. See also W. Wright, Catalogue of the Syriac MSS in the British Museum, 3 vols. (London, 1872), vol. 1, introduction.

${ }^{46}$ The catalogue of this Vatican collection speaks of the extraction of codices $e$ limoso Nili fluminis imo, a wonderfully expressive phrase by its very sound in Latin, meaning "from the muddy bottom of the River Nile." See also Wright's summary of the expeditions of Elias Assemani in 1707 and of J.S. Assemani in 1715 in his Catalogue (reference in the previous note), vol. 1, pp. vi and vii. Elias and Joseph Simon Assemani were both obliged to make a small selection from the MSS of Dayr as-Suryân for purchase. The fact that Ephraim already had a reputation in Europe, albeit one based on the Greek and Latin corpora, may have helped to ensure that Syriac works of his were included in the few MSS selected. The Assemani were Maronites, though, and the Syriac Ephraim was preserved in Maronite liturgical texts to some extent, so this may have influenced their selection, too. The reason why priority was given, back in Rome, to the publication of Ephraim's works is surely the extent of his authority in the Oriental Orthodox Churches; if he could be shown to be Catholic in his doctrine, then the "separated brethren" in the East would have to admit that it was they who had "abandoned their own tradition" (see note 35). 
others edited more works; Mitchell, with great patience and the help of a chemical reagent administered by the British Museum, read the writing which the monk Aaron had washed out and overwritten; Beck and Brock edited various works, Leloir the Gospel Commentary.

Lutheran and High Anglican alike have claimed Ephraim's Eucharistic precedent. The Roman Edition was intended to show that the greatest of the Syriac Fathers had been Catholic in the sense defined by the Vatican and to persuade the "separated" Syrian churches that a union with Rome would be a return to their own roots. Today it is possible to judge him more objectively.

Nevertheless, it can hardly be a coincidence that the two scholars who have gone to the greatest lengths, in the twentieth century, to show that Ephraim's teaching on the Incarnation of Christ agrees with the two-nature formula accepted by the Council of Chalcedon in 451 were Roman Catholics. ${ }^{47}$ If it really does so, why has Ephraim been claimed by the opponents of that Council as a champion?

There is one place in Ephraim's works, Homily on Our Lord XXXIV, where we read that Jesus had two kyonin - the exact equivalent of the Greek phuseis ('natures'). The passage appears to be an interpolation, as even Beck admits; in the last of the late Teaching-Songs on Faith (87:13) he clearly disagrees with those who call Christ "also a human being." 48

Ephraim never doubted that Christ had two births, which in Latin sounds the same as saying that He had two natures (Lat. natus = 'born'); but throughout the Teaching-Songs on Faith he uses kyono only of the divine Son, while pagro stands for the son of Mary and

${ }^{47}$ Edmund Beck, Die Theologie des hl. Ephräm in seinen Hymnen über den Glauben, chapter 4; Louis Leloir, Doctrines et méthodes de S. Éphrem d'après son commentaire de l'évangile concordant (original syriaque et version arménienne) (CSCO 220 = Subsidia 18; Louvain, 1961), chapter 2.

48 Beck, in a note at the end of his German translation of section XXXIV of the Homily On Our Lord (Louvain, 1966), cannot forbear to claim that the passage must have been interpolated by a disciple of Ephraim, faithful to his own phraseology, even though this passage differs in its terminology from that in Ephraim's works on faith. The passage containing the words "also a human being" was translated in my paper in Hugoye 1:2. 
in $84: 14$ he uses the idea of the pearl as a drop of dew solidified inside an oyster as a symbol of this. ${ }^{49}$

Ephraim's doctrine is clearly spelled out in the passages discussed by Beck. Christ is God, the Son; that is his kyono. Jesus is God, clothed in flesh-a kyono from on high which emerged below in the form of a pagro. This "body"-never called Christ's human kyono-bridges the gap between God and humanity. It is wrong to call Christ "human." 50

49 The two best proofs that Beck's interpretation of the Teaching-Songs on Faith, though excellent and clear-headed in other ways, is forced in this regard, come in the last metrical group of the collection, 81-7, which Beck, without explaining why, excludes from his study. The reason cannot be that the Roman edition printed them as a separate collection "On the Pearl," because Beck was using the original manuscripts, in which he must have read the colophon, marking the end of the "eighty-seven madroshe of faith." Even Wright's Catalogue gives clarity about the status of the seven last poems in the cycle in its description of Add. 12, 176. Beck is scathing about the method of the Roman edition and, except in this regard, never omits an opportunity to point out how capricious it is; so he can hardly be excused for using its authority to exclude the most important section of the text under analysis. His edition of the madroshe, which was published six years after his study of their theology, included the last seven poems, but he does not point out in his Foreword the fact that he had erroneously left them out of consideration in his earlier study. His interpretation of the crucial passage, 87:13, in the translation accompanying his edition, is also forced: "er sei fürwahr (nur) Mensch (d-op bar noshaw)." Beck's knowledge of Syriac and his general accuracy command such respect, that it is difficult to excuse these lapses. I suspect also that he used Latin translations of Ephraim's words in his earlier work in order to make the fallacious transition from Ephraim's genuine doctrine of the two births to his alleged doctrine of the two natures less noticeable. However, his integrity as an editor is proved by his judgment that Homily on Our Lord XXXIV, which had been his only explicit support in arguing that Ephraim taught that Christ possessed a human nature, in addition to his divine nature, is a later interpolation.

${ }^{50}$ Louis Leloir, Saint Éphrem: Commentaire de l'évangile concordant: texte syriaque (ms Chester Beatty 709) édité et traduit (Chester Beatty Monographs 8; Dublin, 1963) 250f.: akteb bu d-law barnosho [h]wo = "he [St John] wrote that he was not a human being [but the Word of God]," translated by Leloir as: Scripsit ille non (solum) bominem fuisse illum = "he wrote that he was not (only) a human being." Compare Beck's unwarranted addition of the word "nur" = "only" before "Mensch" = "a human being" in his 
This explains how Ephraim came to be such a hero of the antiChalcedonian Churches. It may also explain why so many in Syriacspeaking Mesopotamia were against the two-nature formula. Ephraim is the father of the Monophysites, even if the name causes offence. Philoxenos of Mabbugh found in Ephraim's writings 106 passages supporting, to his mind, his stand against Chalcedon. ${ }^{51}$

If this gives pause to Ecumenists who are today trying to say that there was never any substantive disagreement on this issue, so much the better. If it makes modern Chalcedonians feel less happy with Ephraim, so much the worse. Dom Beck, OSB, regards his terms as underdeveloped and tries to show that he would have accepted "two natures;" Fr Ortiz de Urbina, SJ, has a more sober assessment.

Recent western Catholic voices (e.g. Dominique Cerbeleau, OP), in the spirit of "Vatican II," do at least deplore his antisemitism, unlike the Orthodox. In no way have his writings furthered the cause of religious tolerance. It may even have been his passion for beauty and harmony which made him so intolerant of those aspects of reality which spoiled his utopian vision. He was an artist.

\section{ANTHOLOGY}

[41] Whether for good or for evil, Ephraim is one of the great names of world literature. At least, he deserves to be better known than he is. As yet there is no version of a work of his in any collection of the world's literary classics. I believe that there ought to be. To illustrate his ability as a writer, I conclude this paper with a short anthology:

translation of Teaching-Songs on Faith 87:13, where Ephraim has another adverb, $o p=$ "also," mistranslated by Beck as fürwahr = "actually (only)" (see the previous note).

51 Philoxenos of Mabbugh, Florilegium patristicum (Patrologia Orientalis 41.1) 58-123; quoted by Mathews Mar Severios in his contribution to the conference, entitled "Ephrem's influence on the christological perspective of Philoxenos." Presumably, the Church of the East, which is diophysite in its doctrine, succeeded in reconciling Ephraim's words with the twonature formula. So far as I know, no one has investigated the christological reception of Ephraim in the Persian Church. 
1. From Part One of the Commentary on the Gospel (in the Harmony made from the Four Gospels by Tatian), section 16. This book, previously known only in an Armenian translation, surfaced in 1957 and was edited by Louis Leloir. A complete and literal English translation by C. McCarthy is available in a volume supplementary to the Journal of Jewish Studies. The present translation is a little freer. Also, I have set it out in such a way as to bring out Ephraim's love of symmetry, even in prose.

When he heard the promise of John from the angel, but did not believe it, he was silent; but when he saw that John had come out of the womb he spoke.

The word which came out of the angel passed by his mouth and closed it, and so came to the womb and opened it; and the same reversed these operations, closing the womb which it had opened, that it might not give birth again, and opening the mouth which it had closed, that it might not be closed again.

It was right that the mouth should be closed for not believing that the barren womb could be opened;

and it was right that the womb which gave birth to John

should be closed and not give birth again, so that an only-begotten son should be the herald of the Only-Begotten Son.

Moreover, even if Zechariah alone doubted, all the same, by doubting, he removed all doubt from people's minds.

2. The first section of the Homily On Our Lord, which is in prose, but verges, at times, on the evenly measured lines of a ballad. The words in italics represent Syriac words on which Ephraim plays: kul/kole (every/holds back); eon/awun (aeon/ hostelry: the "blasphemy" referred to may be Gnosticism, with its language of aeons); ibidoyo/aho (only-begotten/brother); heble/ ḩbolo (birthpangs/corruption); maynqo/qenyone (gives suck/possessions); and there are others I have not marked. Note how the section is rounded by a return to "goodness" and "every mouth." 
Goodness has touched the mouths which insult your divinity;

your creative power makes them into lyres, sounding to the glory of your name.

This is why it is true that "every mouth shall give glory" to the One who bolds back from it any word of blasphemy.

Yours is the glory because he migrated from one aeon and nested in another, in order that He might come to us and make us a hostelry for the One who sent Him.

The Only-Begotten migrated from the sphere of Existence and nested in a uterus unopened, so that a body-birth might render the Brotherless a brother to the many.

He migrated from Sheol and nested in the Kingdom, so as to open the way from the place which cheats all mortals into that which rewards each person.

Our Lord gave mortals his Resurrection as a guarantee that He would remove them from Sheol, which takes in dead people without distinction, and take them to the Kingdom, which allows invited guests to enter with discrimination, so that they might go from one womb, in which the bodies of all people become indistinguishable,

into another womb, in which each person is distinguished

from others by the efforts they have made.

This is the One who went down into Sheol and came up again, so as to take us out of a mother with fruitless pangs and a rotting brood

and bring us into another full of good things, who gives suck to the community she harbours, those who have used possessions, our passing posies and our blossoms in this place, to crown and bedeck for themselves in that place thatched shelters which do not pass away. 
That Firstborn who was born first according to his nature

was born again in a way foreign to his nature, and all for our sake, that we might know that after our own natural birth we actually need to be born again in a way foreign to our nature;

for He is spiritual and until He reached the point of body-birth

He was not able to be bodily; and so it is with the bodily as well:

unless they are born again they are incapable of being spiritual.

So the Son, the manner of whose generation is unintelligible,

was born again in a manner which is intelligible,

that we might learn by the one that his greatness is limitless

and recognize by the other that his goodness is immeasurable.

That his greatness is immeasurably great is evident from his first birth,

which cannot be conceived by any created intelligence;

and that his goodness is limitless

is evident from his second birth, which, as we have seen, is proclaimed by every mouth.

3. This Teaching-Song on the Nativity would have been sung from a permanent wooden platform in the centre of the nave (the bema). The performance of a teaching-song must have been a highpoint in the drama of what happened in church. It would have been a feast for the ears and for the eyes and through them, also, for the mind and for the heart. Here the singer (perhaps a woman) appears in the character of Mary. Like several of Ephraim's songs, this composition is risqué: the theme is incest, underlined by a direct reference to the story of Tamar (there is another incestuous woman of this name in the Bible) and the myth of Myrrha, who consummated a sexual passion for her father and was changed into the bush from which myrrh is produced, as told most recently in the late Ted Hughes's Tales from Ovid (London, 1997). Mary's name is not unlike that of Myrrha. She was fructified by her "father," David, with the "seed" injected into all prophecy-by which all 
prophecy is made fragrant-by her Son. The parallel between mouth and womb, word and child (also found in the passage quoted from the Gospel Commentary) suggests bold sexual parallels for the tongue and for the will which excites it. Ephraim seems to anticipate criticism by making Mary say: "Your praise within my mouth is strange, unheard-of, new." The Syriac word " $b a(d) t h o "$ is here translated three times, to bring out all its meanings. The translation keeps the metre (isosyllabic, rather than iambic, in the original): $(4+4+4)+((4+4)+(4+4))+(4+4$ $+4)$. The response, after each stanza, was: "To You, and through You, to your Sire, we offer praise!"

With You I'll start and so, I trust, with You will end! I'll open wide: You fill my mouth! I'll be the earth: You drive the plough!

You sowed Yourself inside my womb: sow now your Voice!

Unsullied and of noble blood, the Hebrew girls are all amazed at me. Because of You, a lowborn girl is now the envy of them all. But who gave You to me?

What dragged You down to us, to Joseph and to mea needy pair? Well-born, You scorned the well-to-do, despised their wombs. Your traders bring their load of gold to us, the poor!

(She sees the gifts the Magi bring and swells with songs!)

Your worshippers surround me. Look!

Your presents lie around me. Look!

Your Mother is your sounding box; You pluck her strings!

The lyre must face its Lord: my mouth is facing You. My tongue, by your volition, stirs!

Your foetus stirred within my womb.

Your praise within my mouth is strange, unheard-of, new!

To You what's hard is easy. If my womb conceived without the help of sex-gave birth without the help of seed-to You, what's hard about a fruit which swells inside the mouth? 
I'm victimised. I'm wronged. And yet, I'm happy still.

Though all I hear's abuse, to endure these taunts is no great thing to me.

One word from You makes all my tears evaporate!

My honour's not impugned by You, so I walk tall.

I stand accused, but I have borne

the truest Judge! If Tamar won

with Judah's pledge, I, all the more, shall win with yours!

Your father sang a psalm to You before You came.

In naked truth, he sang that men

would offer gold from Sheba's land.

It's happened: look! A pile of gold! A bowl of myrrh!

One hundred psalms — and fifty more- - he sang. And all

are seasoned with your salt. All words

of prophets need your sweetening.

All insights would be tasteless, were it not for You.

4. If Ephraim did write the Epic of Joseph, he intended it for an audience of ordinary people. The style is not as demanding as that of the mimre (let alone the madroshe) on faith; but it is not unlike that of the mimre on Nicomedia or those on the repentance of the Ninevites. It may have been written while Ephraim was still developing his skills, or else by Balai after all; the syntax and the logic of its progression from one image to another are not so polished as those of Ephraim's maturity. For example, the transition to gold in line 19 is very sudden, though implicitly prepared by the antithetical corruptibility of stone; and the change from simile to antithesis in line 24 is not accompanied by an antithetical particle, as in my translation. Lines 24 and 25, when literally rendered, are perhaps a little clumsy: "Gold gathers harms, but the just man gathers successes. / The sins of gold are many; the labours of the good are rich." There are not so many plays on words as we are accustomed to from Ephraim's other works, although there is one on suro, "wall," and swar, "leapt." Some usages, like the plural hawnay, "my wits," may be foreign to Ephraim; but this would need to be shown. The following represents the preface of the epic, as preserved on fol. 103 (recto and verso) of the oldest manuscript, Add. 12,166 (sixth century), which attributes it to Balai. Let the reader judge! 
Envy does evil things to envious men;

the man who's envied, though, is quite immune.

To envy is to lower what one is;

to suffer envy is to win a crown.

For envy is an arrow, harshly barbed, which kills the one who causes it to fly.

His arrow twists against him in his hand; his own deceitfulness will ruin him.

The sower reaps the fruit of what he sows; his fields produce exactly what he gives.

His seed will bring him sorrow if it's bad, for bad will be the harvest that he gets.

If weeds are what he buries in the ground, then brambles will be all the farmer's crop;

But where he broadcasts wheat that's sifted clean, there noble sheaves will stand at harvest-time.

The evil get what they deserve — a loss-

from their deceits and envy-driven plots.

The envied get what they deserve, as well:

a gain, because their Lord stands up for them.

Joseph will illustrate the truth of this;

his brothers teach by their example, too.

The envied one was raised up very high; the envious ones were brought down very low.

The Land of Canaan saw how Jacob's sons, with no good reason, hated Rachel's boy.

Their brother's dreams were wings on which he soared, but they spread out their tricks to cage that bird.

They buried traps to capture that gazelle, but he, light-footed, severed all their ropes.

They were demeaned, diminished by their ploys; the antelope thought little of their nets.

To bar the way he ran, they built a wall; he jumped that wicked fence and cleared it well.

A salty moisture ate away the stones which envious men had built to trap their deer.

If you have gold without impurities, you'll not prevent its going through the fire;

Neither did God protect his righteous one from undergoing terrible ordeals.

By passing through the furnace gold is known to be as pure and lovely as it looks; 
Adverse conditions, likewise,

prove the slave as true and law-abiding as he

seems.

But gold attracts all kinds of harm, as sure as upright character attracts success;

The sins of gold are numberless, whereas the efforts of the good are very rich.

Gold is acceptable to human beings, because it's sweet; and yet, it chokes the mind.

The upright man's acceptable to God, because he teaches God's will here on earth.

Now Joseph loved his God, so who on earth would have no love for Joseph in return?

Compared with one true man, how good is gold? His purity outweighs frivolity.

Nobility is buried in his tale; his company is honey to the tongue.

The thought of him gives pleasure to the mind; a reservoir of wealth lies buried there.

O Good One! You that cherished Jacob's son! Grant me the grace to tell his exploits now!

I do believe your door is open wide because I want to approach your servant's tale.

Oh make my mouth a pathway for his songs and make my tongue a highway for his tales!

Oh let my lips be clashing castanets for odes in honour of him, the champion!

The house of my intelligence is yours to fill with praises of your favourite.

Open my wits like pipes in which You blow, that I may celebrate your family!

You stamped your character on Joseph's own, so grant me grace to tell of his success!

You found him worthy of typifying You, so let us both be enlarged by knowing You!

Your justice did not cheat him of his prize, so let your goodness not let me go short!

He was your friend, and intimate with You. So, for your friendship's sake, let me be, too! 
